\title{
Does governmental venture capital spur invention and innovation? Evidence from young European biotech companies
}

\author{
Fabio Bertoni $^{\mathrm{a}, *}$, Tereza Tykvováa, 1 \\ a Department of Economics, Finance and Control and Research Center on Entrepreneurial Finance (ReCEntFin) of EMLYON Business School, 23 Avenue Guy \\ de Collongue, 69134 Ecully, France \\ ${ }^{\mathrm{b}}$ Institute for Financial Management - Chair of Corporate Finance at the University of Hohenheim, Wollgrasweg 49, 70599 Stuttgart, Germany
}

\section{A R T I C L E I N F O}

\section{Article history:}

Received 22 October 2013

Received in revised form 16 February 2015

Accepted 16 February 2015

Available online 9 March 2015

\section{Keywords:}

Governmental venture capital

Independent venture capital

Patenting

Invention

Innovation

Biotechnology

\begin{abstract}
A B S T R A C T
This paper explores whether and how governmental venture capital investors (GVCs) spur invention and innovation in young biotech companies in Europe. To gauge invention we focus on the simple patent stock at the company level, while innovation is proxied by the citation-weighted patent stock. Our findings indicate that GVCs, as stand-alone investors, have no impact on invention and innovation. However, GVCs boost the impact of independent venture capital investors (IVCs) on both invention and innovation. We conclude that GVCs are an ineffective substitute, but an effective complement, of IVCs. We also distinguish between technology-oriented GVCs (TVCs) and development-oriented GVCs (DVCs). We find that DVCs are better at increasing firm's inventions, and that TVCs, combined with IVCs, support innovations.
\end{abstract}

(C) 2015 Elsevier B.V. All rights reserved.

\section{Introduction}

The latest statistics by the European Venture Capital Association show that, in 2013 , about $40 \%$ of all funds raised by venture capital investors (VCs) in Europe came from governments and that, since 2009, taxpayer's money has systematically been the single largest source of funds to VCs in the continent (EVCA, 2014). Part of this money is directly managed by national and regional public authorities by means of dedicated investment vehicles: governmental VCs (GVCs). Nearly every country in Europe, and many of its regions, set up a GVC. While the specific objectives and structure of these investment vehicles may vary, their underlying aim is to compensate the scarcity of private VC investments, support regional development and promote innovation (Bottazzi et al., 2004; Tykvová, 2006). Have these funds been successful in supporting inventions and innovations in Europe? This paper is a first attempt to answer this question in the context of the biotechnology industry.

VCs are perceived by governments as a key ingredient for achieving the objectives set by the Europe 2020 political

\footnotetext{
* Corresponding author. Tel.: +33478337003.

E-mail addresses: Bertoni@em-lyon.com (F. Bertoni),

Tereza.Tykvova@uni-hohenheim.de (T. Tykvová).

1 Research Associate, ZEW Mannheim, L 7,1, 68161 Mannheim, Germany. Tel.: +4971145924500.
}

agenda, especially in terms of innovation and growth (European Commission, 2011). The relationship between innovations and venture capital has been the subject of an extensive literature. On one hand, the research suggests that VCs are attracted by innovative companies (Baum and Silverman, 2004; Engel and Keilbach, 2007; Hirukawa and Ueda, 2011). On the other hand, the literature shows that inventive and innovative activity is positively affected by the presence of VCs (Arqué-Castells, 2012; Bertoni et al., 2010b; Kortum and Lerner, 2000; Popov and Roosenboom, 2012).

Most of these studies, however, only look at the dominant organizational form of VC: independent VCs (IVCs). IVCs are organized as limited partnerships in which the investment process is run by a management company (the general partners) independently from the ultimate investors (the limited partners). Their aim is to generate financial returns, part of which (the carried interest) remunerates the general partners (Sahlman, 1990). Conversely, GVCs are generally not organized as limited partnerships, their management company is not independent from the ultimate investor (the government), their objectives are not limited to financial returns and their remuneration is usually fixed (Cumming and MacIntosh, 2006; Jääskeläinen et al., 2007). Because IVCs and GVCs differ substantially in terms of objectives, skills and acquaintances, we argue that their impact on companies' inventive and innovative activity will differ.

We will focus on five research hypotheses. First, we will examine whether GVC-backed companies give rise to more corporate 
inventions and innovations than non-VC-backed companies. As invention and innovation often figure explicitly (or implicitly) among the objectives of GVCs, we expect GVC-backed companies give rise to more inventions and innovations than non-VC-backed companies.

Second, we will investigate whether GVCs and IVCs contribute to a different extent to corporate inventions and innovations. On one hand, GVCs might give rise to more inventions in their portfolio companies than IVCs, because a GVC has a longer time-horizon and a stronger orientation to invention, and thus may be more willing to devote resources to risky exploratory activities that give rise to inventions (Sonnek, 2006). On the other hand, compared to their governmental counterparts, IVCs may have better acquaintances, incentives and skills at their disposal to provide companies with resources and support (Bottazzi et al., 2008; Jääskeläinen et al., 2007; Luukkonen et al., 2013), making IVCs more effective than GVCs in spurring inventive and innovative activity.

Our third hypothesis postulates that GVCs and IVCs are complements in their contribution to invention and innovation. To pursue inventive activity, companies need to combine a long-term orientation to invention and innovation and a rich set resources and capabilities. We argue that this is the case when a company is invested by both a GVC and an IVC. On one hand, an IVC may add a significant amount of resources to a GVC-backed company. On the other hand, the presence of a long-term investor like a GVC may increase the ability of an IVC-backed firm to pursue long-term innovation strategies (Hoskisson et al., 2002). A GVC will also add, albeit to a lesser extent, non-duplicate resources to an IVC-backed company. This is because GVCs and IVCs have access to different networks of contacts, have different skills and experience and support differently their portfolio companies (Luukkonen et al., 2013). Accordingly, we expect to observe more inventions and innovations in companies where GVCs and IVCs coinvest than in companies with only one investor type.

Our fourth and fifth hypotheses focus how GVCs differ in their impact on invention and innovation depending on their investment objectives. We distinguish between two types of GVCs: technologyoriented GVCs (TVCs), which have the explicit objective of fostering innovation, and development-oriented GVCs (DVCs), which have economic development as an investment objective. TVCs are organizations with the objective of fostering high-tech companies and innovation in a specific region (e.g., Biom AG Munich, Germany) or at the national level (e.g., ANVAR, France) or GVCs associated to technology transfer offices of universities or research centers (e.g., ISIS Innovation, UK). DVCs, instead, are typically organizations that have the objective of sustaining the economic development at the regional (e.g., SRIW, Belgium) or at the national level (e.g., CDC Capital Investissement, France). The mandate to support invention and innovation, which is explicit for TVCs, is only implicit for DVCs, because invention and innovation contribute to economic development. Therefore, we expect that TVCs will support invention and innovation more than DVCs (Hypothesis 4) and that syndicates between TVCs and IVCs will be more beneficial than syndicates between DVCs and IVCs (Hypothesis 5).

To analyze these hypotheses, we employ a novel database that includes 665 European biotechnology start-ups and young companies, 125 of which are VC-backed, and explore how GVCs affect their patent stock development. The focus on the biotechnology industry reduces the importance of factors (e.g., differences in the determinants of venture capital backing and in the use and valuation of patent) that could not be easily controlled for if we considered a multitude of different industries (Cohen et al., 2000). Moreover, in this industry, patents are an important protecting device for inventions (Hall, 2009; Levin et al., 1987). Besides a simple patent stock, which indicates corporate invention, we also examine qualityweighted patent stock. The literature (Hall et al., 2005, among many others) suggests that quality-weighted patent counts can be used as a proxy for the value of innovation (i.e., invention that is commercially exploited).

Our results on patent stock indicate that, in general, IVC-backed companies generate more inventions than GVC-backed ones. We do not find any significant difference between GVC-backed companies and companies that are not VC-backed. The direct effect of GVCs on invention is thus negligible. However, our analysis suggests that GVCs may be beneficial to invention by complementing the resources provided by IVCs. This result holds for both types of GVCs and, contrary to our expectations, it is larger for DVCs than for TVCs.

We then consider citation-weighted patent stock. The findings confirm that GVC-backed companies do not outperform either IVC-backed companies or non-VC-backed companies. Again, GVCbacked companies do only better than non-VC-backed companies when the GVC syndicates with an IVC. When we distinguish between TVC and DVC, we find a positive effect for TVC-IVC syndicates, but not for DVC-IVC syndicates. Together with the result for the simple patent stock, this finding suggests that DVCs, in syndicates with IVCs, promote inventions, but that most of these inventions are not innovations. This is in contrast to TVCs which, when syndicating with IVCs, are beneficial to both invention and innovation. Our results are robust to different sampling and estimation strategies, the observable and unobservable heterogeneity of portfolio companies and the endogeneity of VC investments.

Our findings add to the literature studying the effectiveness of GVCs. More systematic research in this area is needed (e.g., Lerner, 2009). Many previous works typically focus on one particular government program or one particular country (Alperovych and Hübner, 2014; Avnimelech and Teubal, 2006; Mara, 2011), while our paper includes seven countries. Another contribution of our paper is that we use a micro perspective, while many other works that investigate GVCs impact use a macro perspective and focus on the effect of institutional, legal, cultural and other factors (Groh et al., 2010). Albeit a few recent papers use micro data in a multicountry setting to investigate the effectiveness of GVCs, they focus on issues other than inventions, such as growth (Grilli and Murtinu, 2014) and exit (Brander et al., 2014). We are not aware of any study that would address the effectiveness of GVCs in spurring corporate invention and innovation in this framework. Finally, we add to the literature by discussing how technology-oriented governmental VCs differ from development-oriented governmental VCs in their support of invention and innovation.

The rest of the paper is as follows. Section 2 discusses the theoretical framework. Section 3 gives an overview of our sample. Section 4 describes the results of the empirical analysis. Section 5 provides a discussion and conclusion.

\section{Theoretical framework}

\subsection{Governmental venture capital and innovation}

Invention and innovation require resources that young hightech companies typically lack, but that VCs may offer (Hall and Lerner, 2010).VCs provide financial resources that relax investment constraints (Bertoni et al., 2010a, 2013). But VCs' support to companies' invention and innovation goes well beyond the mere provision of finance. Portfolio companies profit from VCs' industry-specific expertise (De Clercq et al., 2006). Companies may also benefit from VCs' networks (Fried and Hisrich, 1995) towards potential alliance partners, suppliers and customers when establishing, increasing and reconfiguring their resource base. Networks are particularly important for high-tech companies as an integral part of the detection of opportunities, the securing of resources, as well as the 
legitimization of the company (Elfring and Hulsink, 2003). The access to VC's networks is crucial for the inventive and innovative processes in the biotechnology sector, where the locus of inventions is in many cases not in single firms but rather in networks of learning (Powell et al., 1996) and alliances between new entrants and incumbents are common (Gans et al., 2000). Importantly, VCs provide their companies with access to qualified workforce (De Carvalho et al., 2008).

There is, however, an extreme variety in the characteristics of VCs and in the structure of their transactions. The extent to which this variety results in different support to invention and innovation is not yet entirely understood.

In this paper we focus on GVCs, which have, explicitly or implicitly, a mandate to support invention and innovation. Contrary to IVCs, which are independent from the fund providers and have purely financial objectives, GVCs have to respond to economic policy objectives set by the public entity that established them. Specifically, while IVCs are interested in invention and innovation only to the extent to which they increase their return on the investment, GVCs can interested in invention and innovation per se. There are two reasons why GVCs are particularly interested in sustaining innovation. First, because of knowledge spillovers, invention and innovation have a social value beyond what is captured by the innovative companies (Griliches, 1992). Addressing this market failure is one of the fundamental reasons why GVCs are created (Lerner, 1999). Second, knowledge spillovers have a very important local component (Anselin et al., 1997; Breschi and Lissoni, 2001), which means that the positive externalities of invention and innovation will benefit local companies the most. To this extent, a GVC may support invention and innovation because they are instrumental to regional or national economic development.

Our first research question is to understand whether companies backed by GVCs give rise to more invention and innovation than non-VC-backed companies. To a certain extent, GVCs have a similar investment process as traditional VC: they obtain equity stakes in a selected group of companies, support them in their development and eventually exit the investment (Cumming and Johan, 2013). Moreover, as we mentioned above, GVCs have the explicit or implicit objective to promote inventions and innovations. We thus expect GVCs to support the companies' exploratory activities, which spur invention and innovation and results in a positive effect on patenting activities.

Hypothesis 1. GVC has a positive effect on invention and innovation.

The support to portfolio companies beyond the mere provision of finance may differ substantially between GVCs and IVCs because they differ in their objectives, skills, resources and incentives, but it is unclear which of the two investors will provide more valuable resources for invention and innovation. Our second research question is about how GVCs compare to IVCs in supporting invention and innovation of their portfolio companies. This comparison gives rise to two competing hypotheses.

On one hand, if we compare the objectives of IVCs and GVCs, we can conclude that invention and innovation figure more prominently among the objectives of GVCs. GVCs thus might be more willing to devote resources to exploratory activities that give rise to inventions, while this activity might be too lengthy, too risky and too uncertain for IVCs (Sonnek, 2006), which would rather prefer to invest their resources in turning these inventions into commercially used products (Hellmann and Puri, 2000). Moreover, GVCs have a longer time-horizon for their investments than IVCs, which typically have to exit from portfolio companies 5-7 years from their initial investment (Sahlman, 1990). These arguments imply that GVC should have a stronger impact on patenting activity than IVC.
Hypothesis 2a. GVC has a stronger impact on invention and innovation than IVC.

On the other hand other differences between IVCs and GVCs may push in the opposite direction, leading us to an alternative hypothesis. First, in general IVCs possess better skills and resources compared to their governmental counterparts in supporting companies' resource base building (Leleux and Surlemont, 2003; Lerner, 2002; Luukkonen and Maunula, 2007; Luukkonen et al., 2013). Second, due to the structure of their remuneration schemes (Jääskeläinen et al., 2007), IVCs have stronger incentives than GVCs to actively support their companies. If these factors dominate over the differences in objectives between IVCs and GVCs, IVC-backed companies may be more effective in generating inventions and innovations than GVC-backed ones.

Hypothesis 2 b. IVC has a stronger impact on invention and innovation than GVC.

\subsection{Syndication of independent and governmental venture capital investors}

Our third research question is about the complementarity of IVCs and GVCs. We argue that when GVC and IVC syndicate, they may combine their objectives and resources in a way that is more supportive to innovation than when they invest on a stand-alone basis. A company backed by IVC and GVC will have a stronger orientation to invention and innovation than an IVC-backed company and a more complete set of resources than both a GVC-backed and an IVC-backed company.

With respect to the orientation to invention and innovation, Hoskisson et al. (2002) show how the differences in objectives and time-horizons of different investors influence the innovation strategies of their portfolio companies. Specifically, long-term innovation strategies are more likely pursued when long-term investors are present. In our case, this means that invention and innovation, in IVC-backed companies, will benefit from the longterm perspective and interest for innovation brought by a GVC. The presence of a GVC may increase the willingness of IVCs to provide long-term financing as well. Such effect was demonstrated, for example, by Lerner (1999) for the US Small Business Innovation Research program or by Feldman and Kelley (2003) for the US Advanced Technology Program.

As to the resources, the non-financial resources provided by IVCs are not a duplicate of those provided by GVCs but are, at least to a certain degree, different. IVCs can provide the company with unique contacts to qualified workforce, potential alliance partners, suppliers and customers. On the other hand, the GVCs may have a better connection to public institutions, universities and research centers. For instance, some GVCs, like Finlombarda (Milan, Italy), have a close link with local public institutions and support companies in obtaining public funding at local, national and EU level. Other GVCs, like Sopartec (Louvain, Belgium) and ISIS Innovation (Oxford, UK) have very close relationships with universities and public research centers.

GVCs and IVCs also differ in the type of management support they give to portfolio companies and the combination of their support may result in a more complete set of invention-enhancing activities for portfolio companies. While the contribution provided by IVCs tends to be more strategic and technological, GVCs may signal firm's quality to stakeholders and attract additional financing (Lerner, 1999; Luukkonen et al., 2013). While GVCs alone may lack the incentives and ability to put the management sufficiently under pressure to exert effort, a syndicate between an IVC and a GVC may result in a combination of a pressure to deliver and a long-term commitment, which could nurture inventions. 
Hypothesis 3. IVC and GVC are complementary and their effect on invention and innovation is stronger than the sum of their individual effects.

\subsection{Technology-oriented and development-oriented governmental venture capital investors}

Our fourth research question is about whether different types of GVCs have a distinct impact on invention and innovation. Because innovation is by itself a policy objective (Lerner, 1999) promoting innovation is a stated objective of some GVCs, which we call TVCs. Typical objectives of TVCs include: developing innovation (e.g., BIOM, Germany), stimulating the growth of high-tech start-ups (e.g., Alsace Creation, France), investing in technology-advanced and innovative sectors (e.g., ENISA, Spain), supporting spin-offs from public research centers (e.g., ISIS innovation, UK), and financing R\&D (e.g., Bayern Kapital, Germany).

All the GVCs in our sample that do not explicitly state any innovation-related objective have, instead, economic development as their main objective. Examples of these VCs, which we call DVCs, include SODIEX (Spain), Meusinvest (Belgium), CDC Capital Investissement (France), and NRW Bank (Germany). The fact that DVCs do not have innovation as their main objective does not mean that they are not interested in promoting innovation. Because innovation is instrumental to economic development (Munari and Toschi, 2014), even a DVC has, implicitly, the objective of supporting innovation.

According to the agency theory, the effectiveness of a VC will be reduced when its objectives are broad and unclear (Lerner, 1999; Leleux and Surlemont, 2003). We would thus expect that the effectiveness of TVCs in supporting invention and innovation will be more pronounced than that of DVCs, which have broader investment objectives and for which supporting innovation is not an explicit goal.

Hypothesis 4. TVCs are more effective than DVCs in supporting invention and innovation.

Along the same line, we would expect TVC to be more effective than DVC to complement the skills and objectives of IVCs.

Hypothesis 5. The combination of TVC and IVC has a stronger impact on invention and innovation than the combination of IVC and DVC.

\section{Data}

We extract our sample from the VICO dataset. This database has been developed with the support of the 7th Framework Programme promoted by the European Commission (www.vicoproject.org), and it has been used by several recent works (e.g., Croce et al., 2013; Bertoni and Groh, 2014; Grilli and Murtinu, 2014; Cumming et al., 2014; Grilli and Murtinu, 2015). The companies in the VICO dataset were randomly drawn from commercial databases commonly used in scholarly work (e.g., Thomson One, VCPro-Database and Zephyr) and from country-specific datasets (e.g., the yearbooks of the Belgium Venture Capital and Finnish Venture Capital Associations for Belgium and Finland, the ZEW Foundation Panel for Germany, the RITA directory and Private Equity Monitor for Italy, the Web Capital Riesgo Database for Spain, and Venture Source in the UK). The data were cross-checked with information available on VC investors' and investee companies' websites, press releases and other public information sources. A central data-collection team assured that the data were collected consistently and reliably.

The quality assurance effort and the use of a plurality of information sources overcome the limitations of commercial databases. As is well known, commercial databases provide inadequate coverage
Table 1

Sample composition.

\begin{tabular}{lccc}
\hline & All population & VC-backed & $\begin{array}{l}\text { Non-VC-backed } \\
6799\end{array}$ \\
No. of observations & 7896 & 1097 & 182 \\
\hline Distribution & & & 566 \\
Belgium & 332 & 150 & 922 \\
Finland & 717 & 151 & 1381 \\
France & 972 & 50 & 291 \\
Germany & 1735 & 354 & 483 \\
Italy & 336 & 45 & 2974 \\
Spain & 600 & 117 & 1132 \\
UK & 3204 & 230 & 953 \\
Pre-bubble (1984-1997) & 1190 & 58 & 4714 \\
Bubble (1998-2000) & 1056 & 103 & 0.061 \\
Post-bubble (2001-2010) & 5650 & 936 & 0.020 \\
Patent measures (mean) & & & 0.164 \\
Number of patents & 0.075 & 0.047 & \\
Number of passive citations & 0.024 & & \\
\hline
\end{tabular}

Legend: Each observation is one company-year. Number of patents is a simple count of patents granted to the company in a given year. Number of passive citations weights each patent by the number of forward citations.

of VC investments outside of the US. In particular, they tend to overrepresent the role of IVC investors and give only partial coverage of captive investors (e.g., Ivanov and Xie, 2010; Da Gbadij et al., 2014).

All companies in the VICO dataset were founded between 1984 and 2004, operate in high-tech sectors and were independent at foundation. ${ }^{1}$ All VC-backed companies in the VICO dataset were less than 10 years old when they obtained their first financing round, between 1994 and 2004. We extract all companies in the biotechnology sector from the VICO dataset.

In order to classify the GVCs as TVCs or DVCs, we hand-collect information about their investment objectives from their websites and from VC directories (e.g., http://www.crunchbase.com/). We classify an investor as TVC if we find that, among its objectives, innovation, research and development or technology transfer are explicitly stated. Examples include Alsace Creation ("It is particularly focused on technologically advanced and innovative fields of activity") ${ }^{2}$ and Bayern Kapital ("The objective of Bayern Kapital is to finance research and development and market launch of new products") ${ }^{3}$. The GVCs that are not classified as TVCs all have, among their objectives, economic development at the regional (e.g., SRIW, Belgium) or the national level (e.g., CDC Capital Investissement, France). Of the 52 GVCs in our sample, 34 are classified as TVC and 18 are classified as DVC.

Table 1 provides an overview of our sample by country and foundation period. Our panel dataset covers 7896 company-year observations. 3204 observations (40.6\%) are from the UK and 1735 (22.0\%) are from Germany. This distribution is comparable with that of the European biotech sector (OECD, 2006). 1097 observations belong to the VC-backed sample. In our VC-backed sample, Germany, followed by the UK, has the largest number of observations. This is, again, in line with $\operatorname{OECD}$ (2006) data on venture capital investments in biotech. As we cover the whole life of our sample companies (up to 2010), most observations (5650) fall within the period after the burst of the dotcom bubble in 2000 .

To measure corporate inventions, we use patent stock. We define the patent stock of each sample company in year $t$ as follows:

patent stock ${ }_{t}=$ patents $_{t}+(1-\delta)$ patent stock ${ }_{t-1}$,

\footnotetext{
1 A detailed description of the VICO database can be found in Bertoni and Marti Pellón (2011)

2 http://www.invest-alsace.com/supporting-business.php

3 http://www.bayernkapital.de/english
} 
where patents $s_{t}$ is the number of patents granted in year $t$ and $\delta$ is a depreciation rate which we set equal to 15\% (e.g., Griliches, 1998). Several other empirical studies that investigate the relationship between VC and inventions use patents as a proxy for inventions (e.g., Arqué-Castells, 2012; Bertoni et al., 2010b; Mann and Sager, 2007). Swann (2009, page 25) suggests that "Inventions are the culmination of research activity and are ideas, sketches or models of a new product or process, that may often be patented". While the association between patents and invention is widely accepted in the literature, the question is whether patents can also be linked to innovations. Albeit several papers use simple patent counts as a measure of innovation (most recently, e.g., Acharya et al., 2014; Cao et al., 2013), some authors argue that a patent reflects an invention rather that an innovation because many patents are not successfully exploited in terms of a commercial use and, hence, do not qualify as innovations.

Besides simple patent stock, we also employ quality-weighted patent stock that we expect to be closely related to innovation (Hall et al., 2005, among many others). To weight each patent, we use the number of its passive citations, which counts the forward citations of all patents granted to a company in a given year. Citationweighted patent stock may better capture the innovative output of a company than simple patent stock because those patents that are more often cited typically have a higher commercial value. The empirical literature supports this reasoning and demonstrates that passive citations are related to the value of innovation. For example, Hall et al. (2005) argue that passive citations increase the market value of companies measured by Tobin's Q. Harhoff et al. (1999) relate passive citations to economic value, which is assessed through a survey among patent holders. Finally, Lerner et al. (2003) and Aggarwal and Hsu (2014) use citations to measure the importance of a patent.

We collect patent data from PATSTAT, a database delivering information about worldwide applications and grants (with more than 70 million records and over 80 countries), including names of patent assignee, active and passive citations, patent publications, years of application and grant, industry and country scope and other relevant information.

In Table 1 we further report descriptive statistics that highlight how VC-backed companies and their non-VC-backed counterparts diverge in patent counts. The average number of patents granted per year is 0.164 in VC-backed firms and only 0.061 in non-VCbacked companies. A difference of a similar magnitude exists also in terms of citation-weighted patents: $0.047 \mathrm{vs}$. 0.020 .

\section{Results}

\subsection{Univariate analysis}

In order to test our hypotheses, we introduce a number of time-varying VC-related dummies. The IVC dummy identifies IVCbacked companies and it is equal to one after a company has received a financing round from a stand-alone IVC or from a syndicate whose lead investor was an IVC. When investments are syndicated, we focus on the lead investor because it is the most actively involved in the management of the company, while coinvestors play a marginal role (Wright and Lockett, 2003). We identify 531 IVC-backed observations. Similarly, the GVC dummy identifies a company as GVC-backed (491 observations) after a financing round from a stand-alone GVC or from a syndicate led by a GVC. We also distinguish between TVCs (330 observations) and DVCs (161 observations). In addition, we create dummies that specifically identify syndicates between IVCs and GVCs (IVCGVC), IVCs and TVCs (IVCTVC) and IVCs and DVCs (IVCDVC). We obtain 208,
Table 2

Number of patents and passive citations.

\begin{tabular}{lcclll}
\hline \multicolumn{1}{l}{} & Obs. & Mean & Std. dev. & Min & Max \\
\hline Number of patents & & & & & \\
Non VC-backed & 6799 & 0.061 & 0.472 & 0 & 10 \\
IVC & 531 & 0.245 & 0.968 & 0 & 13 \\
GVC & 491 & 0.092 & 0.328 & 0 & 3 \\
$\ldots$ TVC & 330 & 0.085 & 0.338 & 0 & 3 \\
$\ldots$ DVC & 161 & 0.106 & 0.308 & 0 & 1 \\
IVCGVC & 208 & 0.216 & 0.497 & 0 & 3 \\
$\ldots$ IVCTVC & 125 & 0.176 & 0.476 & 0 & 3 \\
$\ldots$ IVCDVC & 83 & 0.277 & 0.526 & 0 & 2 \\
Number of passive citations & & & & \\
Non VC-backed & 6799 & 0.020 & 0.341 & 0 & 17 \\
IVC & 531 & 0.090 & 0.796 & 0 & 11 \\
GVC & 491 & 0.006 & 0.101 & 0 & 2 \\
$\ldots$ TVC & 330 & 0.006 & 0.110 & 0 & 2 \\
$\ldots$ DVC & 161 & 0.006 & 0.079 & 0 & 1 \\
IVCGVC & 208 & 0.111 & 0.989 & 0 & 11 \\
$\ldots$ IVCTVC & 125 & 0.168 & 1.268 & 0 & 11 \\
$\ldots$. IVCDVC & 83 & 0.024 & 0.154 & 0 & 1
\end{tabular}

Legend: Number of patents is a simple count of patents granted to the company in a given year. Number of passive citations weights each patent by the number of forward citations. IVC refers to companies that received VC from a stand-alone IVC or a syndicate led by an IVC. GVC refers to companies that received VC from a stand-alone GVC or a syndicate led by a GVC. TVC refers to companies that received VC from a stand-alone TVC or a syndicate led by a TVC. DVC refers to companies that received VC from a stand-alone DVC or a syndicate led by a DVC. IVCGVC, resp. IVCTVC or IVCDVC, refer to companies that are backed by a syndicate between IVC and GVC, resp. IVC and TVC or IVC and DVC. Non-VC-backed includes companies that did not obtain any venture backing and to VC-backed companies in years before they obtained VC financing.

125 and 83 observations in which the respective variable equals one.

We use this classification to provide some descriptive evidence about the patenting activity of different categories of sample companies, as reported in Table 2 and Fig. 1. In the multivariate regressions, we also control for the presence of other VCs (bankdependent and corporate VCs, which we do not distinguish as separate categories due to their relatively low number) with a dummy Other VC.

In Fig. 1 we report the increase in the patent stock of companies backed by different types of VCs over the patent stock that the companies had at the time of the VC investment. In Panel A of Fig. 1 we also report, for comparison, a trend line indicating the expected increase in the patent stock of a non-VC-backed company over the same time period (computed from the average year-onyear increase in patent stock for the non-VC-backed sample). Panel A shows that patent stock grows more in VC-backed companies than in non-VC-backed ones and we observe differences among different types of VCs. IVC-backed companies have a higher increase in patent stock than GVC-backed companies. The largest increase is observed in companies that are backed by both IVC and GVC. In Panel B we focus on differences between different types of GVCs, and observe that the difference between DVC and TVC is negligible, and that the patent stock grows more in syndicates in which IVC coinvests with DVC rather than TVC.

Table 2 depicts the annual number of patents and passive citations for non-VC-backed companies and for companies backed by different VCs. IVC-backed companies receive on average approximately four times more patents per year $(0.245)$ than non-VC-backed companies (0.061) and four to five times more citations ( 0.090 vs. 0.020$)$. GVC-backed companies have more patents (0.092) than non-VC-backed companies, but they strongly underperform in terms of citations (0.006). TVC-backed and DVC-backed companies have similar patent counts and citations. We notice the most intense patenting activity in companies invested by a syndicate of an IVC and a DVC (IVCDVC): the number of 


\section{Panel A: IVC, GVC and IVCGVC}

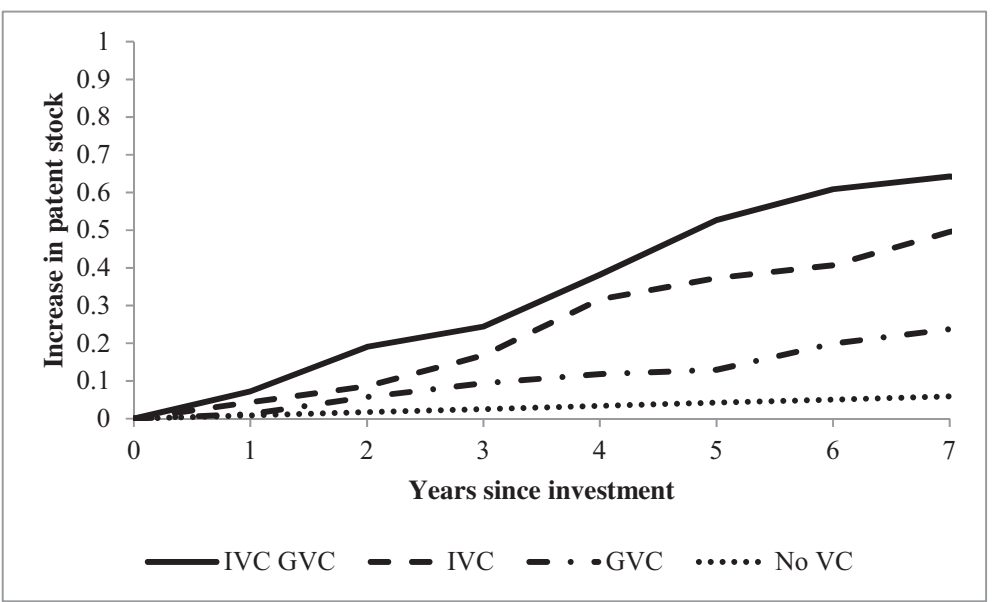

Panel B: TVC and DVC

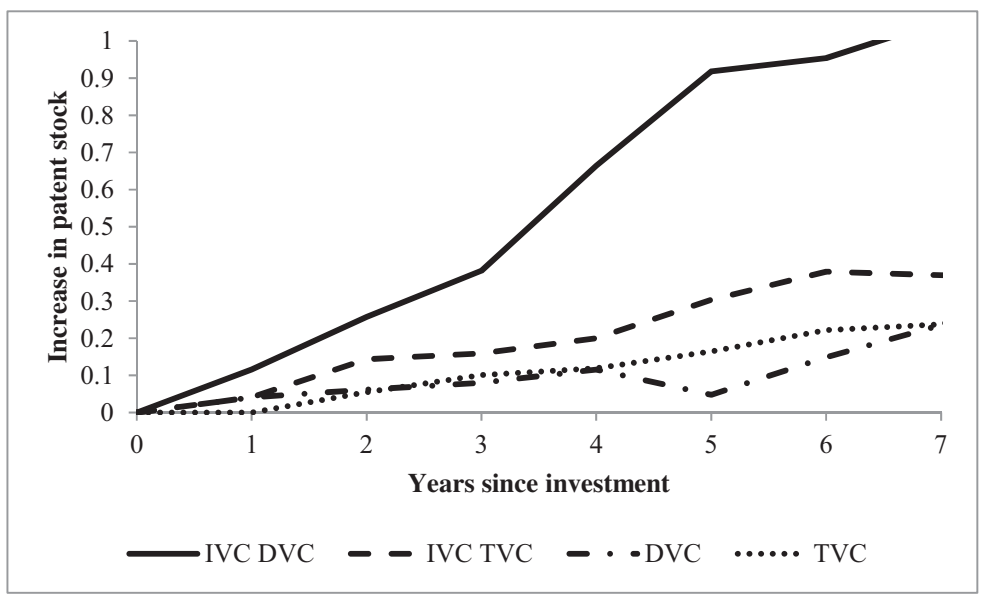

Fig. 1. Increase in patent stock after VC investment.

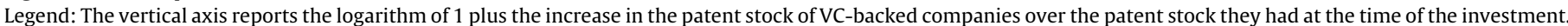

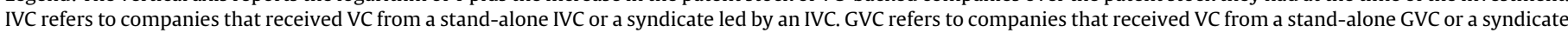

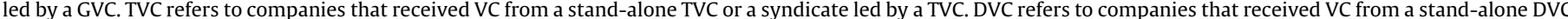

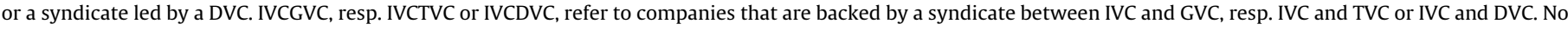
VC, in Panel A, is reported as reference and is obtained from the average annual increase in patent stock of non-VC-backed companies.

patents per year reaches 0.277 . Companies backed by a syndicate of an IVC and TVC (IVCTVC) obtain only 0.176 patents per year on average, but we obtain a completely different picture when we look at citation-weighted patents: IVCTVC-backed companies are the best-performing group and they have on average 7-times more citations than IVCDVC-backed companies.

Table 3 provides univariate tests of our hypotheses. GVC-backed companies patent more than non-VC-backed companies as $\mathrm{H} 1$ predicts. However, we find that, contrary to what H1 suggests, GVC-backed companies have a lower number of citation-weighted patents than non-VC-backed companies. These results may suggest that GVC-backed companies focus on exploratory activity, but that their patents are of a low commercial use (i.e., they are inventions that rarely become innovations). IVC backing is associated to more inventions and innovations than GVC backing and the differences in simple patent counts and citations are statistically significant, which supports H2b. IVCGVC-backed companies outperform nonVC-backed companies as well as companies financed solely by GVCs. These findings suggest, in line with H3, that GVCs may complement the skills and resources provided by IVCs. We do not identify any significant difference between TVCs and DVCs unless these investors syndicate with IVCs. We thus do not find support for H4. The result that IVCTVC-backed companies underperform IVCDVC-backed companies in terms of simple patent counts contradicts H5. If we compare citation-weighted patents, this sign changes (and becomes consistent with $\mathrm{H} 5$ ), and is close to statistical significance ( $p$-value of 0.106 ).

\subsection{Multivariate analysis}

To test our hypotheses in a multivariate setting, we regress the patent stock and citation-weighted patent stock on the different types of VCs discussed in the previous subsection. We use a logarithmic transformation of the dependent variables to reduce the incidence of outliers, which is a common way how to handle patenting data (e.g., Chemmanur et al., 2010). We also control for size of the syndicate, company age and age squared, and time effects (by using year dummies). 
Table 3

Mean comparisons for patents and passive citations.

\begin{tabular}{|c|c|c|}
\hline & Number of patents & Number of citations \\
\hline GVC > Non-VC-backed & $1.92^{* *}$ & $-2.21^{* *}$ \\
\hline$\ldots$ TVC $>$ Non-VC-backed & 1.21 & $-1.86^{* *}$ \\
\hline$\ldots$ DVC $>$ Non-VC-backed & $1.78^{* *}$ & $-1.81^{* *}$ \\
\hline IVC $>$ GVC & $3.23^{* * *}$ & $2.46^{* * *}$ \\
\hline$\ldots$ IVC $>$ TVC & $3.48^{* * *}$ & $2.44^{* * *}$ \\
\hline$\ldots$ IVC $>$ DVC & $2.72^{* * * *}$ & $2.42^{* * *}$ \\
\hline IVC > Non-VC-backed & $4.33^{* * * *}$ & $2.03^{* *}$ \\
\hline IVCGVC > Non-VC-backed & $4.44^{* * *}$ & $1.32^{*}$ \\
\hline ... IVCTVC $>$ Non-VC-backed & $2.67^{* * *}$ & $1.31^{*}$ \\
\hline ... IVCDVC $>$ Non-VC-backed & $3.73^{* * * *}$ & 0.25 \\
\hline IVCGVC $>$ GVC without IVC & $3.76^{* * *}$ & $1.53^{*}$ \\
\hline$\ldots$ IVCTVC $>$ TVC without IVC & $1.98^{* *}$ & $1.41^{*}$ \\
\hline$\ldots$ IVCDVC $>$ DVC without IVC & $3.62^{* * *}$ & $1.43^{*}$ \\
\hline TVC $>$ DVC & 0.68 & 0.02 \\
\hline IVCTVC $>$ ITVDVC & $-1.41^{*}$ & 1.25 \\
\hline
\end{tabular}

Legend: The table depicts the $t$-values of a two-sample $t$ test with unequal variances. Number of patents is a simple count of patents granted to the company in a given year. Number of passive citations weights each patent by the number of forward citations. IVC refers to companies that received VC from a stand-alone IVC or a syndicate led by an IVC. GVC refers to companies that received VC from a standalone GVC or a syndicate led by a GVC. TVC refers to companies that received VC from a stand-alone TVC or a syndicate led by a TVC. DVC refers to companies that received VC from a stand-alone DVC or a syndicate led by a DVC. IVCGVC, resp. IVCTVC and IVCDVC, refer to companies that are backed by a syndicate between IVC and GVC, resp. PVC and DVC. Non-VC-backed includes companies that did not obtain any venture backing and to VC-backed companies in years before they obtained VC financing. ${ }^{* * *},{ }^{* *}$ and ${ }^{*}$ indicate that the coefficients are significant at the two-tailed $1 \%, 5 \%$ and $10 \%$ level, respectively.

One very important challenge in estimating the effect of VC on any measure of firm performance is controlling unobserved heterogeneity. Specifically, results could be biased by unobservable company-specific characteristics that determine both VC financing and innovation (e.g., a better entrepreneurial team may be both better in attracting VCs and more inventive and innovative) and by the fact that VC is attracted by more innovative companies (e.g., Baum and Silverman, 2004; Engel and Keilbach, 2007; Bertoni et al., 2010b). To control for these time-invariant unobservable firm characteristics, we employ fixed-effects regressions (which also capture country-specific effects).

Table 4 shows our results for patent stock. We run five models. Model 1 focuses on differences between companies financed by an IVC, companies financed by a GVC and non-VC-backed companies and thus tests the first two research hypotheses. The coefficient of the GVC dummy is insignificant. Contrary to H1, GVC-backed companies do not have a higher patenting activity than nonVC-backed companies. We find a positive and highly statistically significant effect for IVCs. The patent stock of an IVC-backed company increases by $57 \%$ more than the patent stock of an otherwise comparable non-VC-backed company. ${ }^{4}$ An F-test suggests that the IVC-effect is significantly higher than the GVC-effect. This supports H2b that GVC-backed companies underperform IVC-backed companies in terms of inventions.

In Model 2, we split the GVC dummy into the TVC and DVC dummies, to test whether TVC-backed companies outperform DVCbacked companies as $\mathrm{H} 4$ suggests. We find the opposite effect, namely that DVC-backed companies outperform TVC-backed companies. The patent stock of a DVC-backed company increases by $57 \%$ more than the patent stock of an otherwise comparable nonVC-backed company.

\footnotetext{
4 To obtain this effect, we transform the obtained coefficient (B_IVC) to reflect the logarithmic transformation of the dependent variable. More specifically, we compute the mean relative change in the patent stock (pIVC - p0IVC)/p0IVC as $(\exp ($ B_IVC $)-1) \times(1+$ p0IVC $) / p 0 I V C$, with p0IVC being the mean patent stock in companies that are not IVC-backed.
}

In Model 3 we focus on $\mathrm{H} 3$ and investigate whether syndicates between IVCs and GVCs increase patenting beyond the effect of pure GVCs and pure IVCs. To measure this effect we augment Model 1 by including the IVCGVC dummy. We find that, in line with H3, GVCs and IVCs complement each other. When they syndicate, the observed effect is larger than the sum of the effects of the two investors on a stand-alone basis and is statistically and economically highly significant. The combination of an IVC and a GVC increases the patent stock by $150 \%$ more than what would be expected due to the individual effect of the two investors.

In Model 4, we explore separately IVCTVC and IVCDVC syndicates. We find the complementary effect for both types of GVCs. However, the IVCDVC effect on patent stock is larger than the IVCTVC effect and the difference is statistically significant, which contradicts $\mathrm{H} 5$ (but is consistent with our univariate results). The increase in the patenting activity associated to IVCDVC syndicates is not only statistically significant but also economically. The patent stock of an IVCDVC-backed company increases by $200 \%$ more than what would be expected due to the individual effect of the two investors.

In Models 1-4 we control, using fixed-effects, for all timeinvariant unobserved heterogeneity among sample companies. However, one might argue that time-variant unobserved heterogeneity (e.g., the hiring of a star scientist) might be correlated with both the likelihood of receiving VC and with innovative activity, biasing our results even when we use fixed effects. In order to control for time-variant unobserved heterogeneity we estimate Model 5 using a first-difference generalized method of moments (Arellano and Bond, 1991). The generalized method of moments is widely adopted in the growth and productivity literature to control for the endogenous nature of VC (see, e.g., Bertoni et al., 2011; Grilli and Murtinu, 2014). In the first-difference generalized method of moments (DIF-GMM) approach, the regression model, which includes the lagged dependent variable on the right-hand side, is first-differenced to eliminate time invariant unobserved heterogeneity. A series of moment conditions is then imposed on the first-differenced equations (one for each year of observation) and the over-identified system is then solved to obtain the estimated value of the parameters. The advantage of the DIF-GMM approach is that it is very effective in instrumenting the first-differenced endogenous variables combining external and internal instruments (which include exogenous variables as well as the lagged levels of endogenous variables).

We obtain the external instruments by calculating the relative frequency of investments by different types of VCs in the VICO dataset. The idea behind this instrument is that the activity of different VC types varies across countries and years because of changes in regulation, fundraising, exit conditions, and public markets (Gompers and Lerner, 1999; Gompers et al., 2005; Groh et al., 2010). What makes these variations in VC activity a good instrument is that they affect the likelihood that a particular VC type invests in a given biotech company in a given country and year, but they do not depend on the observed and unobserved characteristics of the company itself. Specifically, we do the following. First, we exclude from the VICO dataset all biotech companies to remove endogeneity in the instrument. Second, we compute, for each country and year, the frequency of IVC-backed, GVC-backed and IVCGVC-backed companies in the non-biotech subsample. These variables capture the relative frequency, in a given country an year, of a particular type of VC. Other things equal, the likelihood that a biotech company is invested by a particular VC type is proportional to how active is that VC type in the country and year. The validity of these instrumental variables is ensured by the fact that they capture structural variations of the venture capital industry across countries and over time and are not correlated to the unobserved characteristics of each specific biotech company in our sample. To 
Table 4

Effect of VC on patent stock.

\begin{tabular}{|c|c|c|c|c|c|}
\hline & Model 1 Fixed-effects & Model 2 Fixed-effects & Model 3 Fixed-effects & Model 4 Fixed-effects & Model 5 Difference GMM \\
\hline \multirow[t]{2}{*}{ IVC } & $0.10^{* * *}$ & $0.10^{* * *}$ & $0.06^{* *}$ & $0.06^{* *}$ & $0.20^{* *}$ \\
\hline & $(0.03)$ & $(0.03)$ & $(0.03)$ & $(0.03)$ & $(0.10)$ \\
\hline \multirow[t]{2}{*}{ GVC } & 0.02 & & -0.01 & & -0.04 \\
\hline & $(0.03)$ & & $(0.03)$ & & $(0.07)$ \\
\hline \multirow[t]{2}{*}{ Other VC } & -0.07 & -0.07 & $-0.08^{*}$ & $-0.08^{*}$ & -0.01 \\
\hline & $(0.05)$ & $(0.05)$ & $(0.05)$ & $(0.05)$ & $(0.05)$ \\
\hline \multirow[t]{2}{*}{ Syndicate size } & $0.12^{* * *}$ & $0.12^{* * * *}$ & $0.07^{* * * *}$ & $0.07^{* * *}$ & 0.05 \\
\hline & $(0.02)$ & $(0.02)$ & $(0.02)$ & $(0.02)$ & $(0.04)$ \\
\hline \multirow[t]{2}{*}{ Age } & $0.01^{* * *}$ & $0.01^{* * *}$ & $0.01^{* * *}$ & $0.01^{* * *}$ & $0.01^{* * *}$ \\
\hline & $(0.00)$ & $(0.00)$ & $(0.00)$ & $(0.00)$ & $(0.00)$ \\
\hline \multirow[t]{2}{*}{ Age $^{2}$} & $-0.00^{* * *}$ & $-0.00^{* * *}$ & $-0.00^{* * *}$ & $-0.00^{* * *}$ & $-0.00^{* * *}$ \\
\hline & $(0.00)$ & $(0.00)$ & $(0.00)$ & $(0.00)$ & $(0.00)$ \\
\hline \multirow[t]{2}{*}{ TVC } & & -0.02 & & -0.04 & \\
\hline & & $(0.04)$ & & $(0.04)$ & \\
\hline \multirow[t]{2}{*}{ DVC } & & $0.11^{* *}$ & & 0.08 & \\
\hline & & $(0.05)$ & & $(0.05)$ & \\
\hline \multirow[t]{2}{*}{ IVCGVC } & & & $0.27^{* * *}$ & & $0.22^{* *}$ \\
\hline & & & $(0.04)$ & & $(0.10)$ \\
\hline \multirow[t]{2}{*}{ IVCTVC } & & & & $0.18^{* * *}$ & \\
\hline & & & & $(0.05)$ & \\
\hline \multirow[t]{2}{*}{ IVCDVC } & & & & $0.35^{* * *}$ & \\
\hline & & & & $(0.05)$ & \\
\hline \multicolumn{2}{|l|}{ Lagged } & & & & $0.47^{* * *}$ \\
\hline & & & & $(0.04)$ \\
\hline $\begin{array}{l}\text { stock } \\
\text { Year dummies }\end{array}$ & Yes & Yes & Yes & Yes & Yes \\
\hline $\mathrm{HO}: \mathrm{IVC}=\mathrm{GVC}$ & $3.11^{*}$ & & 2.55 & & $3.58^{*}$ \\
\hline HO: TVC = DVC & & $4.69^{* *}$ & & $3.66^{*}$ & \\
\hline HO: IVCTVC = IVCDVC & & & & $6.51^{* *}$ & \\
\hline N. observations & 7891 & 7891 & 7891 & 7891 & 6562 \\
\hline AR1 & & & & & $-6.65^{* * *}$ \\
\hline AR2 & & & & & 0.28 \\
\hline Hansen & & & & & 367.47 [596] \\
\hline
\end{tabular}

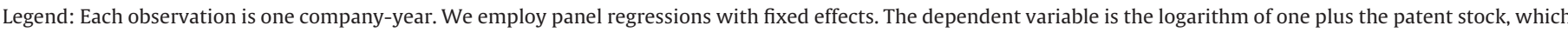

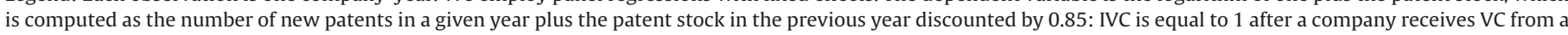

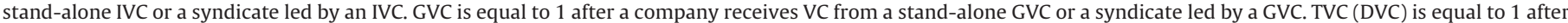

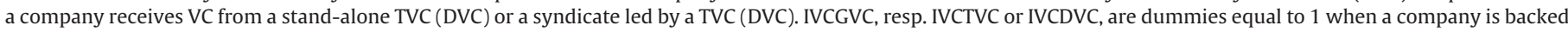

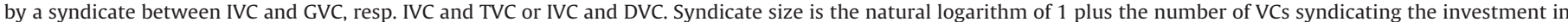

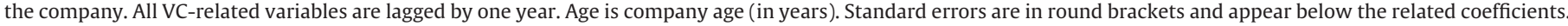

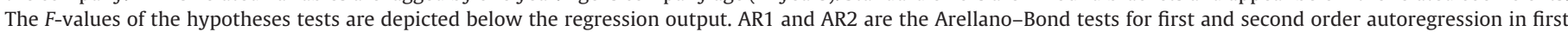

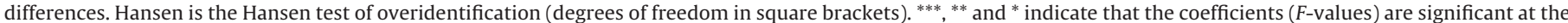
two-tailed $1 \%, 5 \%$ and $10 \%$ level, respectively.

test the strength of the instruments we run a pseudo-first stage regression by estimating three probit models (one for each VC variable we instrument, namely IVC, GVC and IVCGVC) including the relevant instrument and all exogenous variables in the regression (age and its square, country dummies and year dummies). The instrumental variables are all positive and highly significant (z-statistics based on robust standard errors are 9.68 for IVC, 3.94 for GVC, and 5.42 for IVCGVC, all with $p$-value $<1 \%$ ), indicating that the additional instruments are not weak. ${ }^{5}$

The results from Model 5 are in line with those of the corresponding fixed-effect model. Patenting activity, which increases in IVC-backed companies, does not increase in GVC-backed ones, which is against $\mathrm{H1}$, and the difference between IVC and GVC is positive and significant, which supports H2b over H2a. Finally, IVC and GVC are complementary, and the dummy that captures their joint presence (IVCGVC) is positive and significant (albeit at a lower level), supporting $\mathrm{H} 3{ }^{6}$

In Table 5, we run the same five regressions for citationweighted patent stock. We do not find support for $\mathrm{H} 1$ as the

\footnotetext{
5 We choose the DIF-GMM over the SYS-GMM, because the difference-in-Hansen rejects the null hypothesis that the additional moment conditions added in the SYS-GMM are valid $\left(\chi^{2}(75)=205, p\right.$-value $\left.<1 \%\right)$.

${ }^{6}$ Unfortunately, we cannot replicate the DIF-GMM regression for the models in which GVC is split into TVC and DVC, because this distinction is not included in VICO and, hence, we do not have specific external instruments for these investors.
}

coefficient on GVC, TVC and DVC is almost always insignificant (the only exception goes in the opposite direction) suggesting that GVC-backed companies are not more innovative than companies without VC backing. In Model 1, IVC is significant and positive. The citation-weighted patent stock of an IVC-backed company increases by $22 \%$ more than the patent stock of an otherwise comparable non-VC-backed company, but the difference between IVC and GVC turns out to be statistically insignificant. We thus cannot provide support to either H2a or to H2b. In Model 3 , we find support for a positive and highly statistically significant effect for IVCGVC (51\% larger increase in citation-weighted patent stock), consistently with $\mathrm{H} 3$. This result is confirmed in Model 5, where we account for a potential endogeneity by using a DIF-GMM approach, albeit the significance drops at the $10 \%$ level.

While Model 2 suggests that TVC and DVC alone are not supportive to innovations (and no difference exists between them, contradicting H4), in Model 4 we find a strong positive effect of syndicates between IVCs and TVCs on innovative activity (88\% larger increase in citation-weighted patent stock), while the effect of syndicates between IVCs and DVCs is insignificant. Moreover, the difference between these two effects is highly statistically significant, supporting H5. Thus, IVCTVC-backed companies outperform IVCDVC-backed companies in terms of citation-weighted patent stock, while they underperform when we look at the simple patent stock (see Table 4). 
Table 5

Effect of VC on citation-weighted patent stock.

\begin{tabular}{|c|c|c|c|c|c|}
\hline & Model 1 Fixed-effects & Model 2 Fixed-effects & Model 3 Fixed-effects & Model 4 Fixed-effects & Model 5 Difference GMM \\
\hline IVC & $\begin{array}{l}0.04^{* *} \\
(0.02)\end{array}$ & $\begin{array}{l}0.04^{* *} \\
(0.02)\end{array}$ & $\begin{array}{l}0.02 \\
(0.02)\end{array}$ & $\begin{array}{l}0.02 \\
(0.02)\end{array}$ & $\begin{array}{l}-0.11 \\
(0.08)\end{array}$ \\
\hline GVC & $\begin{array}{l}0.01 \\
(0.02)\end{array}$ & & $\begin{array}{l}-0.00 \\
(0.02)\end{array}$ & & $\begin{array}{l}-0.07^{* *} \\
(0.03)\end{array}$ \\
\hline Other VC & $\begin{array}{l}-0.07^{* *} \\
(0.03)\end{array}$ & $\begin{array}{l}-0.07^{* *} \\
(0.03)\end{array}$ & $\begin{array}{l}-0.07^{* *} \\
(0.03)\end{array}$ & $\begin{array}{l}-0.07^{* *} \\
(0.03)\end{array}$ & $\begin{array}{l}-0.01 \\
(0.03)\end{array}$ \\
\hline Syndicate size & $\begin{array}{l}0.03^{* * *} \\
(0.01)\end{array}$ & $\begin{array}{l}0.03^{* * * *} \\
(0.01)\end{array}$ & $\begin{array}{l}0.01 \\
(0.01)\end{array}$ & $\begin{array}{l}0.01 \\
(0.01)\end{array}$ & $\begin{array}{l}-0.02 \\
(0.02)\end{array}$ \\
\hline Age & $\begin{array}{l}0.01^{* * *} \\
(0.00)\end{array}$ & $\begin{array}{l}0.01^{* * *} \\
(0.00)\end{array}$ & $\begin{array}{l}0.01^{* * *} \\
(0.00)\end{array}$ & $\begin{array}{l}0.01^{* * *} \\
(0.00)\end{array}$ & $\begin{array}{l}0.01^{* *} \\
(0.00)\end{array}$ \\
\hline Age $^{2}$ & $\begin{array}{l}-0.00^{* * *} \\
(0.00)\end{array}$ & $\begin{array}{l}-0.00^{* * *} \\
(0.00)\end{array}$ & $\begin{array}{l}-0.00^{* * *} \\
(0.00)\end{array}$ & $\begin{array}{l}-0.00^{* * *} \\
(0.00)\end{array}$ & $\begin{array}{l}-0.00 \\
(0.00)\end{array}$ \\
\hline TVC & & $\begin{array}{l}0.03 \\
(0.02)\end{array}$ & & $\begin{array}{l}-0.00 \\
(0.02)\end{array}$ & \\
\hline DVC & & $\begin{array}{l}-0.02 \\
(0.03)\end{array}$ & & $\begin{array}{l}-0.02 \\
(0.03)\end{array}$ & \\
\hline IVCGVC & & & $\begin{array}{l}0.10^{* * *} \\
(0.02)\end{array}$ & & $\begin{array}{l}0.12^{*} \\
(0.06)\end{array}$ \\
\hline IVCTVC & & & & $\begin{array}{l}0.17^{* * * *} \\
(0.03)\end{array}$ & \\
\hline IVCDVC & & & & $\begin{array}{l}0.04 \\
(0.03)\end{array}$ & \\
\hline Lagged patent stock & & & & & $\begin{array}{l}0.32^{* * *} \\
(0.08)\end{array}$ \\
\hline Year dummies & Yes & Yes & Yes & Yes & Yes \\
\hline HO: IVC= GVC & 1.22 & & 0.99 & & 0.35 \\
\hline H0: TVC = DVC & & 1.72 & & 0.10 & \\
\hline HO: IVCTVC = IVCDVC & & & & $10.96^{* * *}$ & \\
\hline $\begin{array}{l}\text { N. } \\
\text { obser- } \\
\text { va- } \\
\text { tions }\end{array}$ & 7891 & 7891 & 7891 & 7891 & $\begin{array}{l}6562 \\
-3.71^{* * *} \\
0.08 \\
584.47[596]\end{array}$ \\
\hline
\end{tabular}

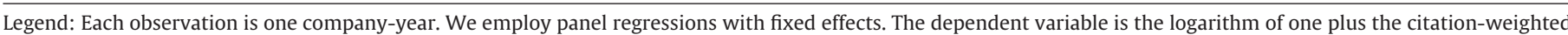

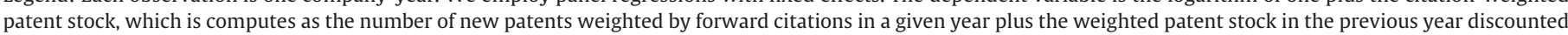

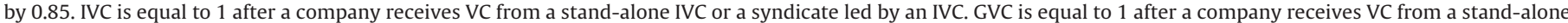

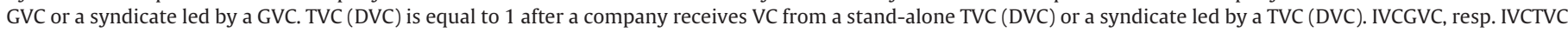

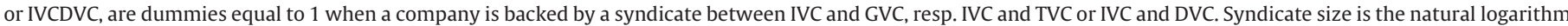

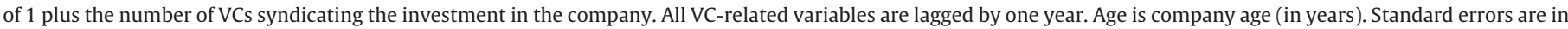

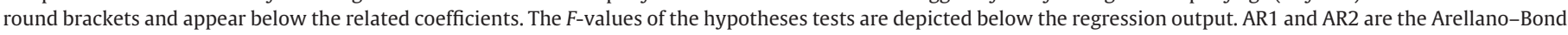

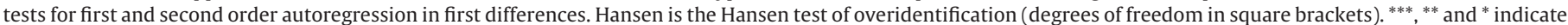
that the coefficients ( $F$-values) are significant at the two-tailed 1\%, 5\% and 10\% level, respectively.

We perform a number of additional analyses to check the robustness of our results. First, we analyze the extent to which our results are robust to sample refinements. We re-run our ten models from Tables 4 and 5 on restricted samples in which we exclude: companies located in the UK (to check whether the results are driven by the sample country with the largest venture capital activity); all observations after one of the VCs exits (in order to account for the fact that the patenting activity may be affected by this event); all companies invested by a VC other than IVC or GVC. Some of the results are of a weaker statistical significance but, all in all, our findings are confirmed. Second, we use different values to depreciate the patent stock ${ }^{7}$ and find that the choice of the depreciation rate makes very little difference. Finally, all key results hold when we use a random effect Poisson regression on patents granted instead of linear model on patent stock.

\section{Discussion and conclusions}

Our paper sheds light on the effectiveness of governmentsponsored equity investments in supporting invention and

\footnotetext{
7 In the main regressions we use a depreciation rate of $15 \%$, as in Bertoni et al. (2010b), Griliches (1998), and Hall et al. (2000). Other commonly used values are 20\% (Ahuja and Katila, 2001; Henderson and Cockburn, 1996) and 30\% (Blundell et al., 1995; Dushnitsky and Lenox, 2005).
}

innovation. Governments throughout Europe have established venture capital funds, often with the explicit aim of supporting innovation. Our study reveals a nuanced picture on their ability to achieve this goal.

A first, and somewhat surprising, result of our study is that, contrary to our expectations and Hypothesis 1, GVC has, on average, no impact on invention and innovation. GVC-backed companies do not patent more than non-VC-backed companies. This holds true for both simple and citation-weighted patent stock. This finding relates to studies that use other performance metrics and show that the performance of GVC-backed companies is, on average, unsatisfactory in terms of exit (Cumming and Johan, 2010; Cumming et al., 2014) and productivity (Alperovych and Hüber, 2014; Grilli and Murtinu, 2014 Grilli and Murtinu, 2014).

When we compare GVC to IVC, we find that IVC-backed companies patent more than both non-VC-backed and GVC-backed companies (even though the difference between IVC and GVC is no longer significant for citation-weighted patent stock). This result supports our Hypothesis $2 \mathrm{~b}$ over Hypothesis 2a. Taken together, the evidence relating to the first two hypotheses suggest that GVC is a poor substitute for IVC.

Albeit a GVC's investment process is often structured to resemble that of an IVC and GVCs often have the explicit objective to foster innovation, the lack of independence from the national or regional government and the low-powered incentives that characterize GVCs' remuneration systems probably deter the most skilled 
investment managers to work for these funds. This, in turn, harms their ability to support invention and innovation in their portfolio companies. From a policymaking perspective, this result means that GVC is not the correct instrument to support invention and innovation in a region where IVC is lacking.

Perhaps the most interesting result of our study is that GVC is an effective complement for IVC. Consistently with our Hypothesis 3 , the combined effect of IVC and GVC goes beyond the individual effect of the two investors. This result is true for both simple and citation-weighted patent stock, and for both fixed-effects and GMM estimation, albeit for citation-weighted patent stock, the coefficient from the GMM estimation is only significant at the $10 \%$ level. This finding suggests that the objective to support invention and innovation and the resources provided by a GVC to its portfolio companies are not enough to boost their inventive and innovative activity if GVC invests on its own, but that they are complementary to the resources provided by an IVC. A recent stream of literature finds similar results about the role of GVCs on other dimensions of firm performance. Brander et al.'s (2014) findings from a large international sample confirm that GVCs are beneficial to successful exits only when they syndicate with private VCs and when the private VC provides a large fraction of funds. ${ }^{8}$ Cumming et al. (2014) obtain similar results on a sample extracted from the VICO database. Grilli and Murtinu (2014), using as well the VICO database, find that syndicates between GVCs and IVCs are the most beneficial for firm productivity growth. From a policymaking perspective, our results mean that GVC is the correct instrument to support invention and innovation in a region where IVC is abundant. Moreover, when setting up GVCs in order to support invention and innovation, governments should try to attract IVC first, and create mechanisms that make GVCs co-invest with IVCs.

Finally, we study how GVCs differ in their impact on innovation depending on their stated objectives. Given our interest on invention and innovation, we distinguish between those funds that have innovation among their stated objectives (TVC) and those that do not (DVC). Our Hypotheses 4 and 5 are not supported if we look at simple patent stock, and only Hypothesis 5 is supported if we look at citation-weighted patent stock. For simple patent stock, not only TVCs' impact on invention and innovation (both as a standalone investor, and in syndication with IVC) is not larger than DVCs' but, as a matter of fact, the opposite is true. For citation-weighted patent stock, neither TVC nor DVC have a significant impact on a stand-alone basis, but TVC's impact on innovation is positive and significant (and larger than DVC's) when syndicating with an IVC. These results mean that DVC-backed companies have patents that are, on average, of a lower quality than those of TVC-backed companies. In other words, DVC seems to be explorative and effective in supporting invention (in line with what Sonnek (2006) suggests for GVC in general), but it is only with the combination of TVC and IVC that innovation is effectively achieved.The explicit objective of fostering high-tech companies and innovation has to be coupled with the support of an IVC, which probably pushes the companies towards the commercialization of their inventions. Without this explicit objective, GVCs seem to motivate their companies to intensive exploratory activities that, however, result in true innovations only in few cases.

Our study opens several avenues for future research. First, while our study was limited to European biotechnology sectors, further research into other regions and industries is warranted, possibly

\footnotetext{
8 Beyond a different performance metrics, our study adds another important piece of evidence to the results found by Brander et al. (2014). The presence of non-VCbacked companies in our sample allows us not only to assess GVC versus IVC, but also to compare GVC against the base case of a non-VC-backed company, while Brander et al. (2014) sample consists of VC-backed companies only.
}

using other measures of innovation. Second, more research, based on qualitative data and questionnaires, is also needed to understand how GVCs and IVCs complement each other in supporting invention and innovation. Third, our distinction between DVC and TVC unveils significant differences among different types of GVCs, and calls for a more fine grained analysis about how their impact differs depending on the geographical (e.g., regional, national or global) and sectoral (e.g., all companies, only high-tech, only young) scope of their investment mandate, their governance structure (e.g., presence external members in the investment committee) and their investment process (e.g., investment horizon, contract terms).

\section{Acknowledgements}

We thank the Editor Martin Kenney and three anonymous referees for their excellent and constructive comments. We would also like to thank: Thomas Åstebro, Massimo Colombo, Frédéric Delmar, Gary Dushnitsky, Alexander Groh, Helmut Kraemer-Eis, Hans Landström, Anne-Laure Le Nadant, Marianna Mazzucato, Miguel Meuleman, Samuele Murtinu, Frédéric Perdreau and all of the participants at the VICO conference in Stresa (Italy), the XXV RENT Conference in Bodø (Norway) and the 12th Symposium on Finance, Banking and Insurance in Karlsruhe (Germany) for their helpful comments. All errors in the manuscript are our own. Support from the 7th European Framework Program (Grant Agreement no. 217485 ) is gratefully acknowledged.

\section{References}

Acharya, V.V., Baghai, R.P., Subramanian, K.V., 2014. Wrongful discharge laws and innovation. Rev. Financ. Stud. 27 (1), 301-346.

Aggarwal, V.A., Hsu, D.H., 2014. Entrepreneurial exits and innovation. Manage. Sci. 60 (4), 867-887.

Ahuja, G., Katila, R., 2001. Technological acquisitions and the innovation performance of acquiring firms: a longitudinal study. Strategic Manage. J. 22 (3), 197-220.

Alperovych, Y., Hübner, G., 2014. How does governmental versus private venture capital backing affect a firm's efficiency? Evidence from Belgium. J. Bus. Ventur., forthcoming.

Anselin, L., Varga, A., Acs, Z., 1997. Local geographic spillovers between university research and high technology innovations. J. Urban Econ. 42, 422-448.

Arellano, M., Bond, S., 1991. Some tests of specification for panel data: Monte Carlo evidence and an application to employment equations. Rev. Econ. Stud. 58, 277-297.

Arqué-Castells, P., 2012. How venture capitalists spur invention in Spain: evidence from patent trajectories. Res. Policy 41, 897-912.

Avnimelech, G., Teubal, M., 2006. Creating venture capital industries that co-evolve with high tech: insights from an extended industry life cycle perspective of the Israeli experience. Res. Policy 35 (10), 1477-1498.

Baum, J.A.C., Silverman, B.S., 2004. Picking winners or building them? Alliance, intellectual, and human capital as selection criteria in venture financing and performance of biotechnology start-ups. J. Bus. Ventur. 19 (3), 411-436.

Bertoni, F., Colombo, M.G., Croce, A., 2010a. The effect of venture capital financing on the sensitivity to cash flow of firm's investments. Eur. Financ. Manage. 16 (4), 528-551.

Bertoni, F., Colombo, M.G., Grilli, L., 2011. Venture capital financing and the growth of high-tech start-ups: disentangling treatment from selection effects. Res. Policy 40, 1028-1033.

Bertoni, F., Croce, A., D'Adda, D., 2010b. Venture capital investments and patenting activity of high-tech start-ups: a micro-econometric firm-level analysis. Venture Cap.: Int. J. Entrepr. Financ. 12 (4), 307-326.

Bertoni, F., Ferrer, M.A., Martí Pellón, J., 2013. The different role played by venture capital and private equity investors on the investment activity of their portfolio firms. Small Bus. Econ. 40 (3), 607-633.

Bertoni, F., Groh, A.P., 2014. Cross-border investments and venture capital exits in Europe. Corp. Gov: Int. Rev. 22 (2), 84-99.

Bertoni, F., Martí Pellón, J., 2011. Financing entrepreneurial ventures in Europe: the VICO dataset. SSRN working paper no. 1,904,297.

Blundell, R., Griffith, R., Van Reenen, J., 1995. Dynamic count data models of technological innovation. Econ. J. 105 (429), 333-344.

Bottazzi, L., Da Rin, M., Hellmann, T.F., 2004. The changing face of the European venture capital industry: facts and analysis. J. Private Equity 7 (2), 26-53.

Bottazzi, L., Da Rin, M., Hellmann, T.F., 2008. Who are the active investors? Evidence from venture capital. J. Financ. Econ. 89 (3), 488-512.

Brander, J., Du, Q., Hellmann, T.F., 2014. The effects of government-sponsored venture capital: international evidence. Rev. Financ., forthcoming. 
Breschi, S., Lissoni, F., 2001. Knowledge spillovers and local innovation systems: a critical survey. Ind. Corp. Change $10(4)$ $975-1005$.

Cao, J., Jiang, F., Ritter, J.R., 2013. Patent- and innovation-driven performance in venture capital-backed IPOs. SSRN working paper No. 2, 364,668.

Chemmanur, T., Loutskina, E., Tian, X., 2010. Corporate venture capital, value creation, and innovation. Boston College Working Paper.

Cohen, W.M., Nelson, R.R., J.P., Walsh, 2000. Protecting their intellectual assets: appropriability conditions and why U.S. manufacturing firms patent (or not), NBER working paper No. 7552.

Croce, A., Martì Pellòn, J., Murtinu, S., 2013. The impact of venture capital on the productivity growth of European entrepreneurial firms: screening or value added effect? J. Bus. Ventur. 28 (4), 489-510.

Cumming, D.J., Grilli, L., Murtinu, S., 2014. Governmental and independent venture capital investments in Europe: a firm-level performance analysis. J. Corp. Financ., forthcoming.

Cumming, D.J., Johan, S.A., 2010. Venture capital investment duration. J. Small Bus. Manage. 48, 228-257.

Cumming, D.J., Johan, S.A., 2013. Venture Capital and Private Equity Contracting, 2nd Edition. Elsevier Science Academic Press.

Cumming, D.J., MacIntosh, J.G., 2006. Crowding out private equity: Canadian evidence. J. Bus. Ventur. 21, 569-609.

Da Gbadij, L.A.G., Gailly, B., Schwienbacher, A., 2014. International analysis of venture capital programs of large corporations and financial institutions. Entrep. Theory Pract., forthcoming.

De Carvalho, A.G., Calomiris, C.W., De Matos, J.A., 2008. Venture capital as human resource management. J. Econ. Bus. 60 (3), 223-255.

De Clercq, D., Fried, V.H., Lehtonen, O., Sapienza, H.J., 2006. An entrepreneur's guide to the venture capital galaxy. Acad. Manage. Perspect. 20 (3), 90-112.

Dushnitsky, G., Lenox, M.J., 2005. Corporate venture capital and incumbent firm innovation rates. Res. Policy 34 (5), 615-639.

Elfring, T., Hulsink, W., 2003. Networks in entrepreneurship: the case of high-technology firms. Small Bus. Econ. 21, 409-422.

Engel, D., Keilbach, M., 2007. Firm-level implications of early stage venture capital investment? An empirical investigation. J. Empir. Financ. 14 150-167.

European Commission, 2011. Regional policy for smart growth in Europe 2020. Available at:

http://ec.europa.eu/regional_policy/information/pdf/brochures/rfec/2011 _smart_growth_en.pdf

EVCA, 2014. 2013 European private equity activity: statistics on fundraising, investments and divestments. Available at: http://www.evca.eu/media/142790/2013-European-Private-EquityActivity.pdf

Feldman, M., Kelley, M.R., 2003. Leveraging research and development: assessing the impact of the US Advanced Technology Program. Small Bus. Econ. 20 (2), $153-165$.

Fried, V.H., Hisrich, R.D., 1995. The venture capitalist: a relationship investor. Calif. Manage. Rev. 37 (2), 101-113.

Gans, J.S., Hsu, D.H., Stern, S., 2000. When does start-up innovation spur the gale of creative destruction? NBER working paper no. 7851

Gompers, P., Kovner, A., Lerner, J., Scharfstein, D., 2005. Venture capital investment cycles: the impact of public markets. J. Financ. Econ. 87 (1), 1-23.

Gompers, P., Lerner, J., 1999. What drives venture capital fundraising? NBER working paper no. 6906

Griliches, Z., 1992. The search for R\&D spillovers. Scand. J. Econ. 94 29-47.

Griliches, Z., 1998. Patent statistics as economic indicators: a survey. In: Griliches, Z. (Ed.), R\&D and Productivity: The Econometric Evidence. University of Chicago Press, Chapter 13.

Grilli, L., Murtinu, S., 2014. Government, venture capital and the growth of European high-tech entrepreneurial firms. Res. Policy, forthcoming.

Grilli, L., Murtinu, S., 2015. New technology-based firms in Europe: market penetration, public venture capital, and timing of investment. Ind. Corp. Change, forthcoming.

Groh, A.P., von Liechtenstein, H., Lieser, K., 2010. The European venture capital and private equity country attractiveness indices. J. Corp. Financ. 16, 205-224.

Hall, B.H., 2009. The use and value of IP rights. In: Working paper presented the UK IP ministerial forum on the economic value of intellectual property, London, UK, 10 June.

Hall, B.H., Jaffe, A.B., Trajtenberg, M., 2005. Market value and patent citations. RAND J. Econ. 36 (1), 16-38.
Hall, B.H., Lerner, J., 2010. The financing of R\&D and innovation. In: Hall, B.H., Rosenberg, N. (Eds.), Handbook of the Economics of Innovation. Elsevier, Amsterdam, pp. 610-638.

Hall, B.H., Jaffe, A.B., Trajtenberg, M., 2000. Market value and patent citations: a first look. NBER working paper no. 7741

Harhoff, D., Narin, F., Scherer, F.M., Vopel, K., 1999. Citation frequency and the value of patented inventions. Rev. Econ. Stat. 81 (3), 511-515.

Hellmann, T., Puri, M., 2000. The interaction between product market and financing strategy: the role of venture capital. Rev. Financ. Stud. 13 (4), 959-984.

Henderson, R., Cockburn, I., 1996. Scale, scope, and spillovers: the determinants of research productivity in drug discovery. RAND J. Econ. 27 (1), 32-59.

Hirukawa, M., Ueda, M., 2011. Venture capital and innovation: which is first? Pac Econ. Rev. 16 (4), 421-465.

Hoskisson, R.E., Hitt, M.A., Johnson, R.A., Grossman, W., 2002. Conflicting voices: the effects of institutional ownership heterogeneity and internal governance on corporate innovation strategies. Acad. Manage. J. 45 (4), 697-716.

Ivanov, V.I., Xie, F., 2010. Do corporate venture capitalists add value to start-up firms? Evidence from IPOs and acquisitions of VC-backed companies. Financ. Manage. 39 (1), 129-152.

Jääskeläinen, M., Maula, M., Murray, G., 2007. Profit distribution and compensation structures in publicly and privately funded hybrid venture capital funds. Res. Policy 36, 913-929.

Kortum, S., Lerner, J., 2000. Assessing the contribution of venture capital to innovation. RAND J. Econ. 31 (4), 674-692.

Leleux, B., Surlemont, B., 2003. Public versus private venture capital: seeding or crowding out? A pan-European analysis. J. Bus. Ventur. 18, 81-104.

Lerner, J., 1999. The government as venture capitalist: the long-run effects of the SBIR program. J. Bus. 72 (3), 285-318.

Lerner, J., 2002. When bureaucrats meet entrepreneurs: the design of effective public venture capital programmes. Econ. J. 112, F73-F84.

Lerner, J., 2009. Boulevard of Broken Dreams: Why Public Efforts to Boost Entrepreneurship and Venture Capital Have Failed - and What to Do about it Princeton University Press.

Lerner, J., Tirole, J., Strojwas, M., 2003. Cooperative Marketing Agreements Between Competitors: Evidence from Patent Pools. National Bureau of Economic Research, NBER Working Paper No. 9680.

Levin, R.C., Klevorick, A.K., Nelson, R.R., Winter, S.G., 1987. Appropriating the returns from industrial research and development. Brook. Pap. Econ. Act. (3), 783-831.

Luukkonen, T., Deschryvere, M., Bertoni, F., Nikulainen, T., 2013. The value added by government venture capital funds compared with independent venture capital funds. Technovation 33 (4-5), 154-162.

Luukkonen, T., Maunula, M., 2007. Non-financial value-added of venture capital: a comparative study of different venture capital investors. ETLA Discussion paper No. 1067

Mann, R.J., Sager, T.W., 2007. Patents, venture capital, and software start-ups. Res. Policy 36, 193-208.

Mara, A.S., 2011. Maximizing the returns of government venture capital programs. Defense Horizons, January 2011. Available at: http://www.dtic.mil/cgi-bin/GetTRDoc?Location=U2\&doc=GetTRDoc.pdf \&AD\&9552;ADA536817

Munari, F., Toschi, L., 2014. Assessing the impact of public venture capital programmes in the United Kingdom: do regional characteristics matter? J. Bus. Ventur., forthcoming.

OECD, 2006. Biotechnology Statistics. OECD Publishing., http://dx.doi.org/10.1787/9789264015821-en.

Popov, A.A., Roosenboom, P., 2012. Venture capital and patented innovation: evidence from Europe. Econ. Policy 27 (71), 447-482.

Powell, W.W., Koput, K.W., Smith-Doerr, L., 1996. Interorganizational collaboration and the locus of innovation: networks of learning in biotechnology. Admin. Sci. Quart. 41 (1), 116-145.

Sahlman, W.A., 1990. The structure and governance of venture-capital organizations. J. Financ. Econ. 27 (2), 473-521.

Sonnek, D., 2006. Tapping venture capital's horn of plenty. EIRMA Innovation Quarterly, available at http://www.eirma.org/eiq/009/pages_html/eiq-2006-009-0005.html

Swann, G.M.P., 2009. The Economics of Innovation: An Introduction. Edward Elgar Publishing.

Tykvová, T., 2006. How do investment patterns of independent and captive private equity funds differ? Evidence from Germany. Financ. Markets Portfolio Manage. 20 (4), 399-418.

Wright, M., Lockett, A., 2003. The structure and management of alliances: syndication in the venture capital industry. J. Manage. Stud. 40, 2073-2102. 